\title{
CHRONOLOGY OF EVENTS
}

Late 8th century Spartan conquest of Messenia

$669 / 8$

Sparta defeated by Argos at Hysiae

Mid- to late

Second Messenian War, Sparta adopts the "Great

7 th century

Rhetra," Tyrtaeus

c. 632

Cylon attempts to establish a tyranny in Athens

c. 621

Draco's legislation at Athens

594

Solon archon, mediator, and lawgiver in Athens

$5^{60-55^{6}}$

Supposed first tyranny of Peisistratus in Athens

$546-528$

Peisistratus tyrant in Athens

$5^{28-5} 5^{10}$

Hippias tyrant in Athens

$5^{14}$

Harmodius and Aristogeiton assassinate Hipparchus

$5^{10}$

Tyrant family expelled from Athens by Spartan intervention

$5^{08 / 7}$

Factional strife in Athens, intervention by King Cleomenes of Sparta, popular uprising against Isagoras and Cleomenes, reforms initiated by Cleisthenes

$5^{\mathrm{o} 6}$ Failed Spartan invasion of Attica, Athens defeats Chalcis and Boeotians

499-494 Ionian Revolt, initially supported by Athens and Eretria 490 First Persian invasion, Athenian victory at Marathon

$483-480$ Construction of large Athenian war fleet

$480-479$

Second Persian invasion, Greek defeat at Thermopylae, draw at Artemisium, victories at Salamis, Plataea, and Mycale 
478

472

465

$4^{6} 3$

$462 / 1$

$459^{-45^{1}}$

$45^{8}$

$45^{1 / 0}$

$44^{6}$

443

$43^{1-40} 4$

429

413

$4^{11}$

$4^{10}$

410-399

404

403

399
Foundation of Delian League under leadership of Athens

Performance of Aeschylus's Persians

Earthquake and helot revolt at Sparta

Performance of Aeschylus's Suppliants

Reforms initiated by Ephialtes, Cimon ostracized

First Peloponnesian War between Athens and Spartan alliance

Performance of Aeschylus's Oresteia, including Eumenides

Pericles' citizenship law

Thirty Years' Peace with Sparta

Ostracism of Thucydides son of Melesias, Pericles' last major opponent

Second Peloponnesian War

Death of Pericles

Defeat of Athenian expeditionary force in Sicily

Oligarchy of the Four Hundred at Athens, followed by a moderate oligarchy of Five Thousand

Democracy restored

Revision of laws in Athens

Defeat of Athens, tyranny of the Thirty

Democracy restored

Trial and death of Socrates 